\title{
Morphometric and DNA Barcoding of endemic Halmaheran walking shark (Hemiscyllium halmahera, Allen, 2013) in North Maluku, Indonesia
}

\author{
HAWIS MADDUPPA ${ }^{1, \vartheta}$, ARINI S. P. PUTRI ${ }^{1}$, RIDHO Z. WICAKSONO ${ }^{1}$, BEGINER SUBHAN ${ }^{1}$, \\ NEBUCHADNEZZAR AKBAR ${ }^{2}$, FIRDAUT ISMAIL ${ }^{2}$, DONDY ARAFAT ${ }^{1}$, DERTA PRABUNING $^{3}$, \\ L.M. IQBAL SANI ${ }^{3}$, ENDANG S. SRIMARIANA ${ }^{1}$, ABDURRACHMAN BAKSIR ${ }^{2}$, DIETRIECH G. BENGEN ${ }^{1}$ \\ ${ }^{1}$ Department of Marine Science and Technology, Faculty of Fisheries and Marine Sciences. Institut Pertanian Bogor. J1 Agatis, Kampus IPB Dramaga, \\ Bogor 16680, West Java, Indonesia. Tel.: +62-251-8623644, `email: hawis@apps.ipb.ac.id \\ ${ }^{2}$ Faculty of Fisheries and Marine Sciences, Universitas Khairun. Jl. Jusuf Abdulrahman, Ternate 97719, North Maluku, Indonesia \\ ${ }^{3}$ Oceanogen Environmental Biotechnology "Laboklinikum”. Jl Cemara 3 No. 34, Taman Yasmin, Bogor 16111, West Java, Indonesia \\ ${ }^{4}$ Misool Baseftin Foundation, Jl. Basuki Rahmat Ruko No. 8, Km. 8 (depan bandara DEO), Kota Sorong 98416, Papua Barat, Indonesia
}

Manuscript received: 21 April 2020. Revision accepted: 27 June 2020.

\begin{abstract}
Madduppa H, Putri ASP, Wicaksono RZ, Subhan B, Akbar N, Ismail F, Arafat D, Prabuning D, Sani LMI, Srimariana ES, Baksir A, Bengen DG. 2020. Morphometric and DNA Barcoding of endemic Halmaheran walking shark (Hemiscyllium halmahera, Allen, 2013) in North Maluku, Indonesia. Biodiversitas 21: 3331-3343. The walking shark (Hemiscyllium halmahera) commonly referred to as bamboo shark, is a shark species that belongs to the Hemiscyllidae family which is endemic in North Maluku, and Indonesian waters. These Hemiscyllium species are generally confined to the Australian-New Guinea region, save a specie which originates from Halmahera, an Indonesian island. Ever since its discovery, sufficient information on its existence has been largely unavailable. Hence, the purpose of this study is (1) to assess the morphology, using meristic measurements and length-weight relationship, and (2) to determine the molecular characteristics through DNA barcoding, phylogenetic reconstruction, and genetic diversity. The samples used in this research were obtained from Halmahera Archipelago, North Maluku, including Halmahera, Tidore, Ternate, Maitara, and Guraici in several expeditions between March 2017 and January 2018. 36 individuals in total were measured for morphometric parameters including Total Length (TL), Standard Length (SL), Head Length (HL), Body Circumference (BC), and Body Weight (BW). Out of a total of 36 sharks, tissue samples were obtained from 32 individuals for molecular identification. After the required measurements were obtained, all individuals sharks were released back to their habitat safely. Equations of linear regression were used to analyze the relationship between length and weight. Morphometric measurements indicated that the average total length of the walking shark samples obtained, were not more than $75 \pm \mathrm{cm}$ for both male and female specimens. The length-weight analysis revealed a positive allometric growth pattern in $\mathrm{H}$. halmahera species, where weight was gained faster than an increase in length. The results of the DNA fragment length analysis from all samples were 793-bp. All 32 tissue samples identified as H. halmahera consisted of 3 samples from Ternate Island, 14 samples from Maitara Island, 9 samples from Guraici Island (South Halmahera), 10 samples from Central Halmahera, and 2 samples from Tidore Island. These results confirmed that DNA subsequence analysis indicates that H. halmahera is different from those sequences extracted from Genbank in the Australia-New Guinea region. This study successfully identified H. halmahera based on their morphological and molecular characters, and has therefore contributed to international genetic database (Barcoding Of Life Database-BOLD) for further studies.
\end{abstract}

Keywords: Complex species, coral triangle, endemic species, length-weight relationship, phylogenetic reconstruction

\section{INTRODUCTION}

The walking shark, commonly referred to as bamboo shark, is a species of sharks that belong to the Hemiscyllidae family, which consists of two genera, Hemiscyllium and Chiloscyllium (Allen et al. 2013, Jutan et al. 2017). The Hemiscyllium has a small body, usually lesser than $85 \mathrm{~cm}$, u (TL) with a total length averaging about $70 \mathrm{~cm}$. Different shades are present on all parts of its body, with a small transverse mouth located under its eye, two dorsal fins of the same size, and a long, slender tail (Allen et al. 2016, Jutan et al. 2017, Akbar et al. 2019). These walking sharks are nocturnal animals that live at the bottom of waters or coral reef areas, mangroves, and seagrasses or ponds that are naturally formed with fluctuating tides. (Compagno 2002). The Hemiscyllidae family features include strong muscular pectoral characteristics which help to support the unique habit of these "walking" sharks, when searching for prey in the form of small fish, benthic invertebrates and crustaceans found in the deep crevices of corals (Allen et al. 2013).

Nearly all of its species are oviparous; they lay their capsule-like eggs at the bottom of the waters. (Compagno 2002). Due to this reproductive system, this species has a low distribution. The walking shark is commonly found in Australia, Indo-Australian islands, and New Guinea, in the Western Pacific (Allen et al. 2013). However, one species is endemic to Indonesia, the H. halmahera, precisely in Halmahera, which is located about $130 \mathrm{~km}$ from Raja Ampat, which belongs to the Papua New Guinea Western 
Group. Etymologically, the nomenclature of its genus Hemiscyllium comes from the Latin and Greek words (skylion), hemi, which denotes part and scyllium, which means dogfish (Allen et al. 2016). Halmahera itself is used as its name, because these species were first found in Halmahera, not far from the main island, which is usually shallow and no more than 50-100 m (Allen et al. 2016).

Hemiscyllium halmahera was first discovered by $\mathrm{M}$. Erdmann while doing night dives on Ternate Island (Allen et al. 2013). Ever since it's discovery, accurate study and information on distribution and population in Halmahera Island and surroundings $H$. halmahera has been largely unavailable. This information is important to support the management and conservation of this ecologically valuable species. Also, species belonging to this family were discovered to be complex for morphological species identification, which is essential for making a comprehensive database for further studies. The reason for identification is to search for those characteristics that can biologically distinguish one individual from another (Sallis et al. 2018). However, the species in the genus Hemiscyllium have almost the same morphology, and this renders it difficult to distinguish their various specimens morphologically. Therefore the DNA barcoding method is needed to perform accurate identification on a specie level. The DNA barcoding method is a molecular taxonomic method and is a reliable tool used for specieslevel identification (Sembiring et al. 2014, Madduppa et al. 2016, Hellberg et al. 2019). The DNA barcoding method uses a polymer in the PCR process to amplify DNA up to 600-700 bp (Prehadi et al. 2015) even Almerón-Souza et al. (2018) found that it could be done with a length of 204-600 bp. Furthermore, due to the hunting of these species by the local fishermen, (Jutan et al. 2018) their genetic diversity may have been affected, thus making them vulnerable. Genetic diversity is required for the determination of the magnitude of genetic variation that shows the genetic source needed for adaptation in both the short and long term (Bramandito et al. 2018). The research conducted by Momigliano et al. (2017) shows that mtDNA can be used to demonstrate the differences between the shark populations. Hence, mtDNA was utilized in this study. Genetic variation is necessary for operating the basic mechanism of revolutionary change. Another essential source of genetic variation is genetic mixing. (Madduppa, 2014). Therefore, this study is aimed at: (i) assessing the morphology, using meristic measurements and LengthWeight relationships, and (ii) determining the molecular characteristics through DNA barcoding, phylogenetic reconstruction, and genetic diversity, from Halmahera Archipelago, North Maluku, and other locations such as Halmahera, Tidore, Ternate, Maitara and Guraici.

\section{MATERIALS AND METHODS}

\section{Study area}

This study was conducted in Halmahera Archipelago, North Maluku, Indonesia as well as Halmahera, Tidore, Ternate, Maitara, and Guraici in multiple research expeditions between March 2017 and January 2018 (Figure 1). Halmahera Island, which was formerly known as Jilolo, Gilolo, or Jailolo, is the largest island in the Maluku Islands, where Sofifi which is the capital of the province is situated. Halmahera is located on the west coast of the island. Tidore Island is located in the west of Halmahera Island. During the pre-colonial era, the Sultanate of Tidore was a significant regional political and economic power, as well as a great rival of nearby Ternate, just to the north. Ternate is the largest city in the Indonesian province of North Maluku and was previously the capital of the former Sultanate of Ternate and the de facto provincial capital of North Maluku before being moved to Sofifi in 2010. The geographical area of Maitara Island is not as big as Ternate or Tidore and lies between the southern island of Tidore and Ternate Island. Those islands contain lots of mangroves, seagrasses, and coral reefs.

There are four species of mangroves that have been discovered in these areas, and they include Rhizophora apiculata, R. mucronata, R. stylosa and Soneratia alba (Subur and Sarni 2018), which are frequently occupied by $H$. halmahera during the day, usually found at the roots resting (Figure 2). Because of their stealthy, quiet behavior, the Halmaheran Walking Shark is also called gecko sharks, known for moving stealthily at the bottoms of the waters, seagrasses, and around coral reef areas (Figure 2).

\section{Morphological assessment}

The morphological characters of walking sharks were observed and matched with the identification key, according to Allen et al. (2013). Hemiscyllium sp. can be distinguished based on the color patterns that are visible on their bodies. Morphometric measurements and body weight were also observed and noted to ascertain the growing diversity of walking sharks. These morphometric parameters included (Figure 3): Total Length (TL) which is measured from the tip of the head to the tip of the caudal fin; Standard Length (SL) measured from the tip of the head leading to the base of the caudal fin; Head Length (HL) which is measured from the tip of the head leading to the last gill curve; and Body Circumference (BC) measurements made in areas that have the largest diameter in the body of a fish, usually found behind the pectoral fin. . Measurements are obtained by looping the meter in the area. The weight of each individual was measured using a digital scale (gram), and sex was observed by their clasper or cloaca (Figure 4). After all measurements, all sharks were safely released back into their habitat. 


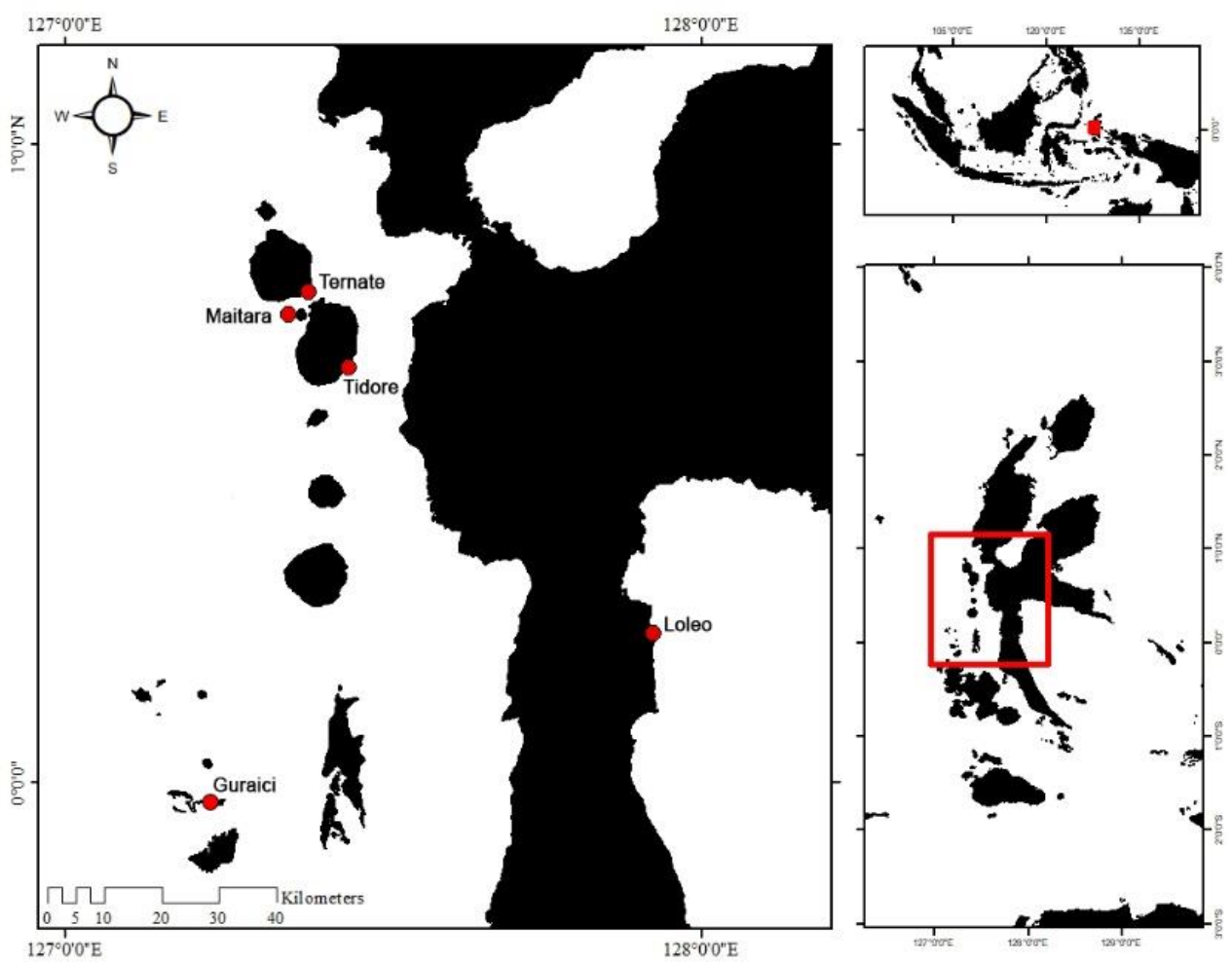

Figure 1. Tissue sample collection sites of Hemiscyllium halmahera of five distinct populations in Halmahera Archipelago, North Maluku.
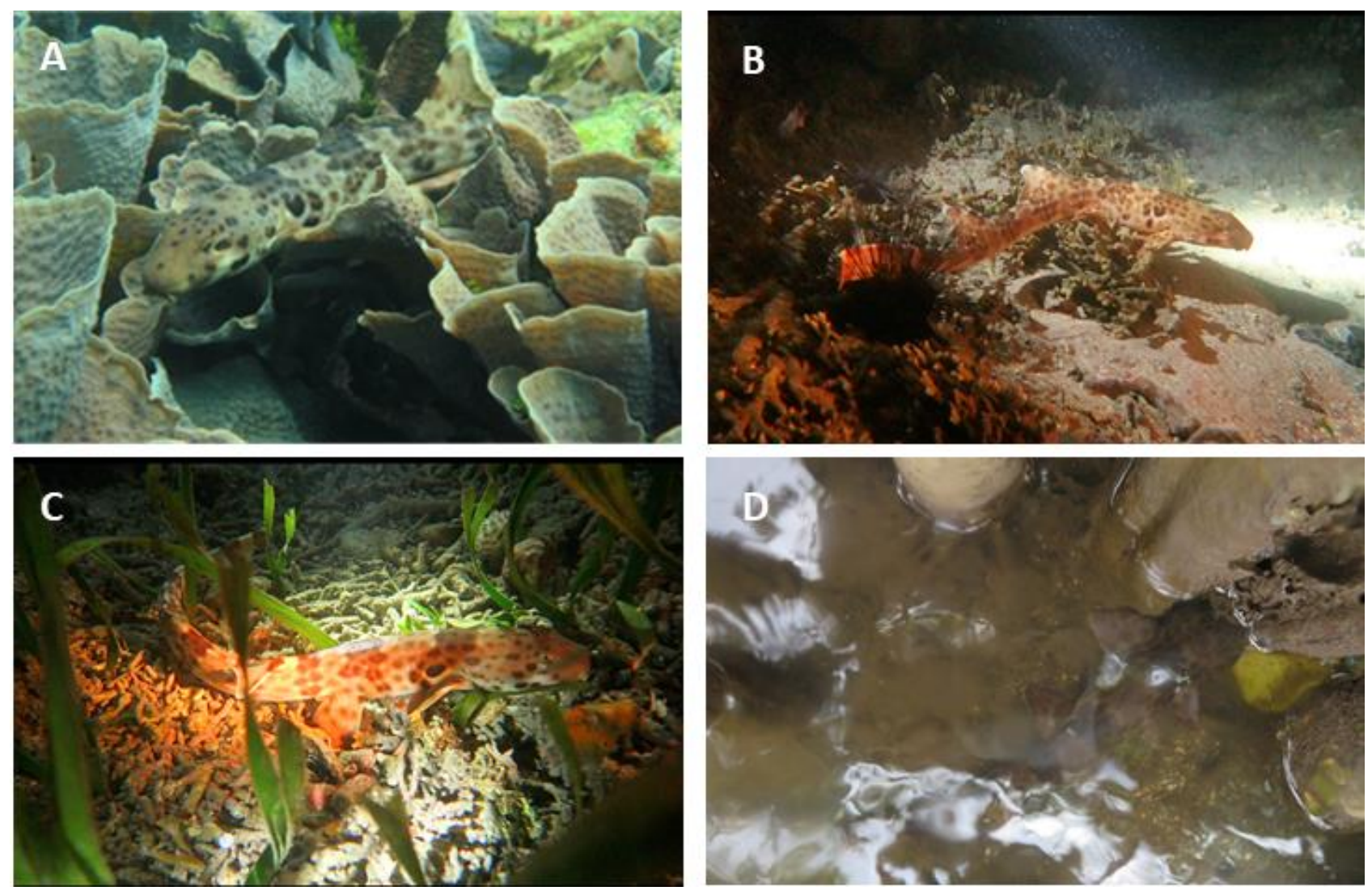

Figure 2. Hemiscyllium halmahera sightings. They were encountered at several habitats including during sample collection at night and day in coral reefs ecosystem (A, B), seagrass meadows (C), and between roots of mangroves (D) 


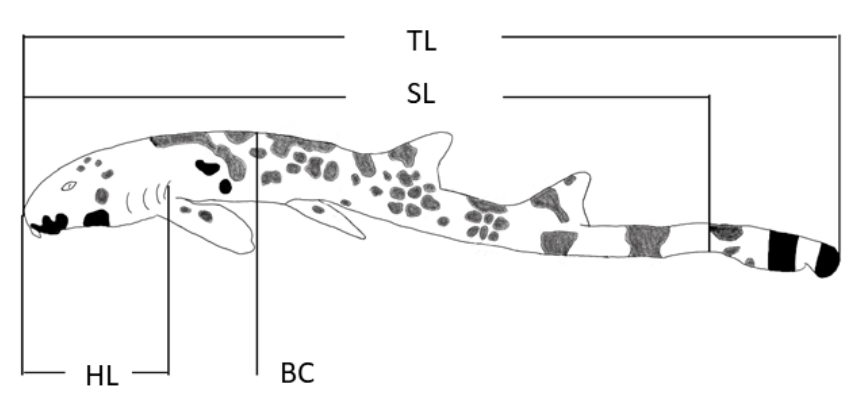

Figure 3. Morphometric measurement of Hemiscyllium halmahera showing total length (TL), standard length (SL), head length (HL), body circumference (BC).

\section{Molecular analysis}

Tissue sampling

A total of 32 tissue samples were obtained as part of the skin of walking shark fin using scissors. The samples were collected and placed in a tube containing $96 \%$ ethanol, and given an information code on each tube. The tissue sampling process was carried out at a depth of 5 meters within the mangrove, seagrass, and coral reef ecosystems.

\section{DNA extraction}

The aim of DNA extraction is to obtain tissue from the sample, make pure extractions, and protect the DNA from degradation. In this study DNA extraction was carried out via the Chelex method. The Chelex method is a DNA extraction method that uses a $10 \%$ chelex solution manufactured from a mixture of chelate-resin and $\mathrm{H} 2 \mathrm{O}$ solution (Walsh et al. 1991). In this method, $10 \mathrm{mg}$ of a finely cut shark fin tissue sample was taken and placed into a $1.5 \mathrm{ml}$ tube containing a $10 \%$ Chelex solution, vortexed for 10 seconds, then centrifuged for 10 seconds and then heated in a hot block at $95^{\circ} \mathrm{C}$ for three hours. After this heating, the sample was vortexed again for a total of 10 seconds and centrifuged for 10 seconds respectively to ensure that all of its content is at the bottom of the microcentrifugation tube. Note that the extraction stage must be sterile and gloves must be used to prevent contamination.

\section{Electrophoresis}

The first step in the method of electrophoresis involves making $1 \%$ agarose gel containers $(50 \mathrm{ml}$ TBE buffer and $0.5 \mathrm{~g}$ agarose). Next, the solution is heated in a microwave and cooled. A coloring agent is then added $(3 \mu \mathrm{L}$ of Ethidium Bromide (EtBr). Afterward, add a total of $3 \mathrm{PCl}$ of PCR results to agarose wells. Run the electrophoresis machine at a voltage of $220 \mathrm{~V}$ and a current of $400 \mathrm{~mA}$ for 20 minutes. The results obtained from the electrophoresis process can be observed using ultraviolet transilluminator light.

\section{DNA amplification and sequencing}

DNA amplification or PCR involves the stages of DNA multiplication in a target organism. The PCR process was repeated for about 20-30 cycles, and during each cycle, three stages were carried out, namely denaturation, annealing, and extension (Metzker 2005). Components on the PCR are $3 \mu \mathrm{L}$ DNA templates, $12.5 \mu \mathrm{L}$ My taq $2 \mathrm{x}$ HS Red Mix, $1.25 \mu \mathrm{L}$ forward and reverse primers, and $9 \mu \mathrm{L}$ ddH2O. Primary used ND4-F: 5 'CACCTATGACTACCAAAAGCTCATGTAGAAGC-3' (Arevalo et al. 1994) and H12293-Leu-R: 5 'TTGCACCAAGAG-TTTTT GGTTCCTAAGACC-3' (Inoue et al. 2001). During the PCR process, a Thermocycler machine from PeqLab was used with a program to target the mitochondrial NADH Dehydrogenase 4 gene (ND4), namely pre denaturation $95^{\circ} \mathrm{C}$ for a duration of 5 minutes, denaturation $95^{\circ} \mathrm{C}$ for 15 seconds, annealing $56^{\circ} \mathrm{C}$ for 30 seconds, extension $72^{\circ} \mathrm{C}$ for 1 minute with a total cycle of 30 times, and a final extension of $72^{\circ} \mathrm{C}$ for 7 minutes (Allen et al 2013). Sequencing is one of the methods for obtaining nucleotide base sequence structure in DNA. The sequence of nucleotide bases is related to each individual's derivatives (Metzker 2005). DNA sequencing is used to determine the sequence of nucleotide bases in DNA segments. DNA sequences provide genetic information derived either from the nucleus (cell nucleus), plasma, mitochondria, or chloroplasts of a living thing. Positive DNA, which is the PCR product, is then sent to the sequencing company for nucleotide sequencing.

\section{Data analysis}

\section{Morphological analysis}

Morphometric character variations were analyzed using the PCA (Principal Component Analysis) method, which functions to simplify variables into several distinct components so that a simple relationship between variables can then be explained (Bengen 2000). Analysis of the length-weight relationship in $H$. halmahera using the general formula $\mathrm{W}=[\mathrm{aL}]^{\mathrm{b}}$ where $\mathrm{W}$ stands for weight (grams), L for body length $(\mathrm{cm})$, a and b denote constant values that were obtained from the regression value (Effendie 1979). Analysis of length-weight relationship using linear regression equations was done using Microsoft Excel. If the value of $\mathrm{b}$ is equal to 3 , then it is said to be isometric, meaning that the length and weight are directly proportional. If the value of $b$ is smaller than 3 , then the increase in length or growth occurred faster than weight. This is referred to as a negative allometric, and if the value of $b$ is greater than 3, then the increase in weight is faster than growth in length, which is therefore known as a positive allometric (Effendie 1979).

\section{Molecular analysis}

All DNA sequences were aligned and edited using the MEGA 6.0 (Molecular Evolutionary Genetics Analysis) (Tamura et al. 2013). The results obtained from the aligned nucleotide data are then matched to the data contained in GenBank at NCBI (National Center for Biotechnology Information) using the BLAST (Basic Local Alignment Search Tool) (http: //blast.ncbi.nlm.nih.-gov). After the BLAST results have been obtained, a phylogeny tree was reconstructed using the Neighbour Joining and Maximum Likelihood Tree method using a bootstrap number of 1000 with the Kimura-2 Parameter model. In the phylogenetic 
tree branches, several bootstrap values are present, and they function to unveil the accuracy of the phylogenetic tree branches (Horiike et al 2009). This tree was created using 32 sequences of $H$. halmahera of this current study with an additional 12 sequences from GenBank. Bootstrap values equaling up to to $95 \%$ indicate that branching is accurate, consistent, and will not change if other phylogenetic tree methods are used. If the bootstrap value is higher than $70 \%$, this means that a permanent or significant branching (Coenye et al 2003). The genetic diversity was observed and analyzed using DNAsp 5.0 software (Rozas et al. 2003) which was then followed by analysis using Arlequin 3.5 (Excoffieer and Lischer 2010) including the haplotype diversity $(\mathrm{Hd})$ and nucleotide diversity $(\pi)$ values for each population (Nei 1987). All sequences have been uploaded to the Barcode of Life Data System (BOLD) with a sequence page range of HWSWS001-19 to HWSWS03219.

\section{RESULTS AND DISCUSSION}

\section{Morphological characteristics}

Hemiscyllium halmahera has a physical morphology of a relatively slender, tapered backward tail, two dorsal fins of the same size, and a long and slender fin shape. Having a short, blunt snout, the location of the nostrils is at the tip of the snout, with a short tentacle and smallmouth. The region of the mouth, and its teeth consist of many lines that are synonymous with sidewalks. Based on the results observed using the identification key, Hemiscyllium halmahera has two large black spots that are shaped polygonal on the ventral snout. On the anterior aspect of the head, there are a pair of black spots on the surface of the abdomen and the head giving a hood-like semblance (Figure 4).

Table 1 shows the morphometric measurements for each walking shark. Each measurement showed that the total length of the individual walking shark samples obtained was not higher than $75 \mathrm{~cm}$ with an average of $52.3 \pm 10.2 \mathrm{~cm}$, both for male and female specimens. A total of 22 individual walking sharks were identified as males, while the other 10 individuals were identified as females. The males were larger than females (Table 2).

The analysis of the length-weight relationship applies the least-square equation which collects and calculates data for males and females. Table 3 Length-Weight Relationship of Hemiscyllium halmahera. Figure 5 represents the analytical results of the length-weight relationship of $H$. halmahera. The results obtained from the analysis of the weight and length show that the value of $b$ is within the range of 3.386 and 11.957 . Therefore, based on the value of the constant $b$, it can be inferred that the growth of body length in endemic walking sharks occurs faster than increasing weight or negative allometric.
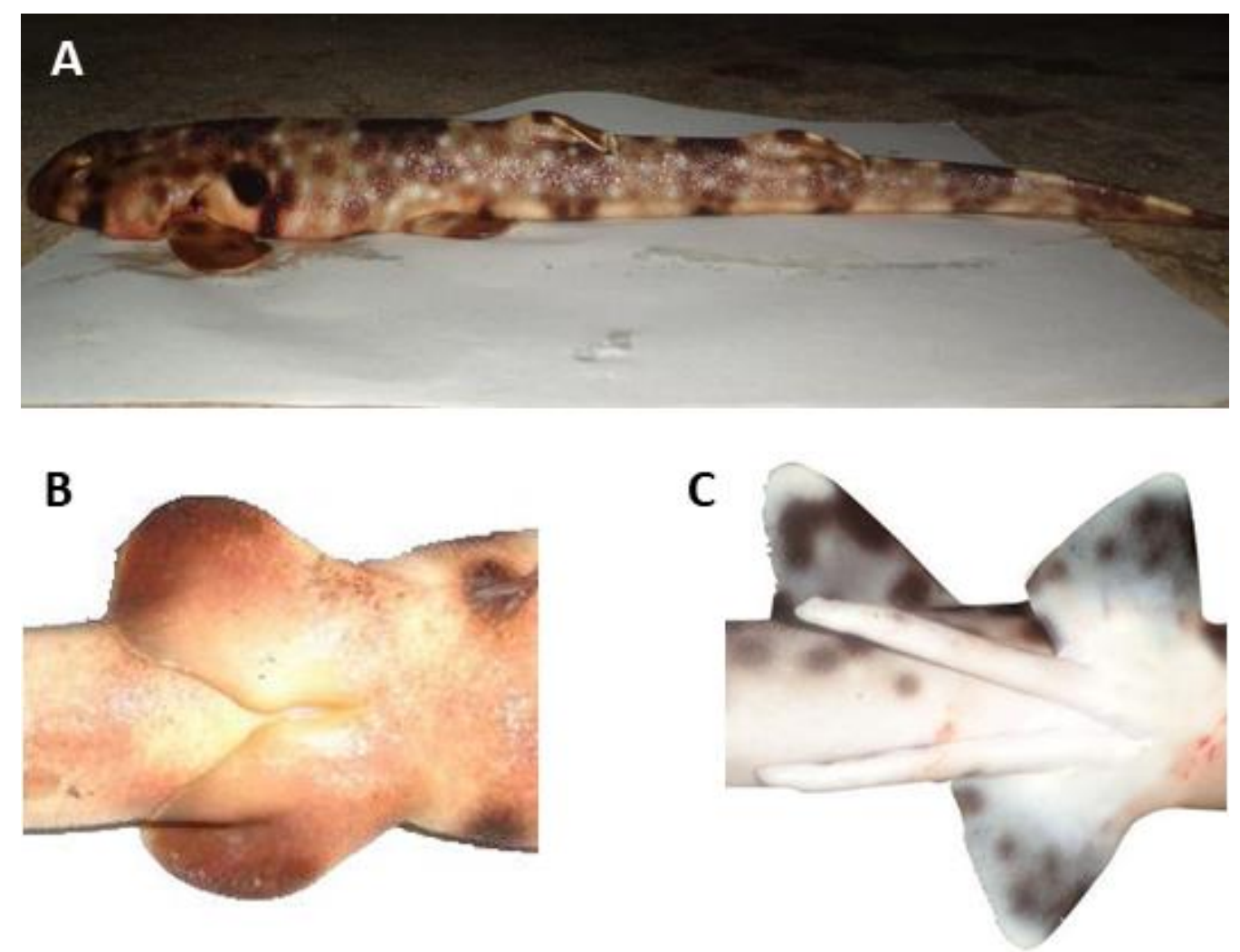

Figure 4. A. Specimen of Hemiscyllium halmahera during morphological assessment before they were released back into their habitat, B. Female sex genital with cloaca, and C. Male sex genital with clasper 
Table 1. Summary of a comprehensive data collection at each site with sample ID including the meristic of individual Hemiscyllium halmahera which was found at their habitat in each site by measuring Total Length (TL), Standard Length (SL), Head Length (HL), body circumference (BC), and body weight (BW) in situ. Length measurements are in centimeter $(\mathrm{cm})$ and weight in grams (g). Sex $($ Male $=\mathrm{M}$, Female $=\mathrm{F})$

\begin{tabular}{|c|c|c|c|c|c|c|c|c|c|}
\hline Site & Coordinates & Sample ID & $\mathbf{T L}$ & SL & HL & $\mathbf{B C}$ & BW & Sex & Habitat \\
\hline Maitara & N 0044'.471" E $127^{\circ} 21^{\prime} .998^{\prime \prime}$ & ITK_Mai_WS_01 & 53 & 49 & 10 & 14 & 410 & M & Coral reefs \\
\hline Maitara & N 0044'.471'’'E 127²1'.998', & ITK_Mai_WS_02 & 49 & 47 & 9 & 14 & 400 & M & Coral reefs \\
\hline Maitara & N 0044'.471" E $127^{\circ} 21^{\prime} .998^{\prime \prime}$ & ITK_Mai_WS_03 & 58 & 50 & 11 & 16 & 400 & M & Coral reefs \\
\hline Maitara & N 0044'.471" E $127^{\circ} 21^{\prime} .998^{\prime \prime}$ & ITK_Mai_WS_04 & 51 & 47 & 9 & 14 & 400 & $\mathrm{~F}$ & Coral reefs \\
\hline Maitara & N 0044'.471" E $127^{\circ} 21^{\prime} .998^{\prime \prime}$ & ITK_Mai_WS_05 & 54 & 50 & 9 & 15 & 410 & M & Coral reefs \\
\hline Maitara & N 0044'.471" E $127^{\circ} 21^{\prime} .998^{\prime \prime}$ & ITK_Mai_WS_06 & 42 & 37 & 7 & 11 & 300 & $\mathrm{~F}$ & Seagrass \\
\hline Maitara & N 0044'.471" E $127^{\circ} 21^{\prime} .998^{\prime \prime}$ & ITK_Mai_WS_07 & 53 & 50 & 8 & 14 & 400 & M & Seagrass \\
\hline Maitara & N $00^{\circ} 44^{\prime} .471^{\prime \prime}$ E $127^{\circ} 21^{\prime} .998^{\prime \prime}$ & ITK_Mai_WS_08 & 52 & 47 & 8 & 15 & 400 & $\mathrm{~F}$ & Seagrass \\
\hline Maitara & N $00^{\circ} 44^{\prime} .471^{\prime \prime}$ E $127^{\circ} 21^{\prime} .998^{\prime \prime}$ & ITK_Mai_WS_09 & 40 & 37 & 7 & 11 & 290 & $\mathrm{~F}$ & Mangrove \\
\hline Maitara & N $00^{\circ} 44^{\prime} .471^{\prime \prime}$ E $127^{\circ} 21^{\prime} .998^{\prime \prime}$ & ITK_Mai_WS_10 & 41 & 37 & 7 & 11 & 300 & $\mathrm{~F}$ & Mangrove \\
\hline Maitara & N $00^{\circ} 44^{\prime} .471^{\prime \prime}$ E $127^{\circ} 21^{\prime} .998^{\prime \prime}$ & ITK_Mai_WS_11 & 51 & 48 & 10 & 15 & 390 & M & Seagrass \\
\hline Maitara & N $00^{\circ} 44^{\prime} .471^{\prime \prime}$ E $127^{\circ} 21^{\prime} .998^{\prime \prime}$ & ITK_Mai_WS_12 & 61 & 57 & 12 & 16 & 400 & $\mathrm{M}$ & Seagrass \\
\hline Maitara & N $00^{\circ} 44^{\prime} .471^{\prime \prime}$ E $127^{\circ} 21^{\prime} .998^{\prime \prime}$ & ITK_Mai_WS_13 & 58 & 54 & 9 & 14 & 600 & M & Coral reefs \\
\hline Maitara & N $00^{\circ} 44^{\prime} .471^{\prime \prime}$ E $127^{\circ} 21^{\prime} .998^{\prime \prime}$ & ITK_Mai_WS_14 & 57 & 52 & 9 & 14 & 500 & $\mathrm{~F}$ & Coral reefs \\
\hline Guraici & N 00²7'.496" E $127^{\circ} 23^{\prime} .885^{\prime \prime}$ & ITK_Halsel_WS_03 & 55 & 53 & 10 & 17 & 400 & M & Coral reefs \\
\hline Guraici & N $00^{\circ} 27^{\prime} .496^{\prime \prime}$ E $127^{\circ} 23^{\prime} .885^{\prime \prime}$ & ITK_Halsel_WS_04 & 60 & 57 & 11 & 23 & 600 & M & Coral reefs \\
\hline Guraici & N 00²7'.496" E $127^{\circ} 23^{\prime} .885^{\prime \prime}$ & ITK_Halsel_WS_06 & 53 & 50 & 9 & 16 & 400 & M & Coral reefs \\
\hline Guraici & N $00^{\circ} 27^{\prime} .496^{\prime \prime}$ E $127^{\circ} 23^{\prime} .885^{\prime \prime}$ & ITK_Halsel_WS_07 & 53 & 49 & 10 & 17 & 400 & M & Coral reefs \\
\hline Guraici & N $00^{\circ} 27^{\prime} .496^{\prime \prime}$ E $127^{\circ} 23^{\prime} .885^{\prime \prime}$ & ITK_Halsel_WS_08 & 60 & 58 & 10 & 18 & 400 & $\mathrm{M}$ & Coral reefs \\
\hline Guraici & N 00²7'.496" E $127^{\circ} 23^{\prime} .885^{\prime \prime}$ & ITK_Halsel_WS_09 & 37 & 35 & 6 & 8 & 200 & M & Coral reefs \\
\hline Loleo & N $00^{\circ} 14^{\prime} .650^{\prime \prime}$ E $127^{\circ} 55^{\prime} .129^{\prime \prime}$ & ITK_Halteng_WS__01 & 40 & 37 & 7 & 11 & 290 & $\mathrm{~F}$ & Coral reefs \\
\hline Loleo & N $00^{\circ} 14^{\prime} .650^{\prime \prime}$ E $127^{\circ} 55^{\prime} .129^{\prime \prime}$ & ITK_Halteng_WS_02 & 48 & 44 & 10 & 14 & 310 & M & Seagrass \\
\hline Loleo & N 00¹4'.650" E $127^{\circ} 55^{\prime} .129^{\prime \prime}$ & ITK_Halteng_WS_05 & 34 & 33 & 6 & 7 & 190 & M & Coral reefs \\
\hline Loleo & N 00¹4'.650" E $127^{\circ} 55^{\prime} .129^{\prime \prime}$ & ITK_Halteng_WS_06 & 33 & 31 & 6 & 6 & 190 & M & Coral reefs \\
\hline Loleo & N $00^{\circ} 14^{\prime} .650^{\prime \prime}$ E $127^{\circ} 55^{\prime} .129^{\prime \prime}$ & ITK_Halteng_WS_07 & 52 & 50 & 8 & 15 & 390 & M & Seagrass \\
\hline Loleo & N $00^{\circ} 14^{\prime} .650^{\prime \prime}$ E $127^{\circ} 55^{\prime} .129^{\prime \prime}$ & ITK_Halteng_WS_08 & 54 & 52 & 9 & 18 & 400 & M & Seagrass \\
\hline Loleo & N $00^{\circ} 14^{\prime} .650^{\prime \prime}$ E $127^{\circ} 55^{\prime} .129^{\prime \prime}$ & ITK_Halteng_WS_10 & 42 & 39 & 8 & 13 & 300 & $\mathrm{~F}$ & Coral reefs \\
\hline Tidore & $\mathrm{N} 00^{\circ} 38^{\prime} .59 .47^{\prime \prime}$ E $127^{\circ} 26^{\prime} 42.41^{\prime \prime}$ & ITK_Tidore_WS_01 & 57 & 54 & 9 & 17 & 500 & $\mathrm{~F}$ & Coral reefs \\
\hline Tidore & N 00³8'.59.47" E $127^{\circ} 26^{\prime} 42.41^{\prime \prime}$ & ITK_Tidore_WS_02 & 60 & 57 & 11 & 19 & 500 & $\mathrm{~F}$ & Coral reefs \\
\hline Ternate & N $0^{\circ} 46{ }^{\prime} 57.7^{\prime \prime}$ E $127^{\circ} 23^{\prime} 20.0^{\prime \prime}$ & ITK_Ternate_Hiu_01 & 74 & - & - & - & - & M & Seagrass \\
\hline Ternate & N $0^{\circ} 466^{\prime} 57.7^{\prime \prime}$ E $127^{\circ} 23^{\prime} 20.0^{\prime \prime}$ & ITK_Ternate_Hiu_02 & 70 & - & - & - & - & M & Seagrass \\
\hline Ternate & N $0{ }^{\circ} 466^{\prime} 57.7^{\prime \prime}$ E $127^{\circ} 23 ' 20.0^{\prime \prime}$ & ITK_Ternate_Hiu_03 & 73 & - & - & - & - & M & Coral reefs \\
\hline
\end{tabular}

Table 2. Comparison of meristic between males and females of Hemiscyllium halmahera by comprehensive measurement of Total Length (TL), Standard Length (SL), Head Length (HL), Body Circumference (BC), and Body Weight (BW) in situ. Length measurements are in centimeter $(\mathrm{cm})$ and weight measurements in gram $(\mathrm{g})$.

\begin{tabular}{lccc}
\hline & Female $(\mathbf{n}=\mathbf{1 0})$ & Male $(\mathbf{n = 2 2})$ & All sex $(\mathbf{n = 3 2})$ \\
\hline TL $(\mathrm{cm})$ & $48.2 \pm 8.0$ & $54.2 \pm 10.6$ & $52.3 \pm 10.2$ \\
SL $(\mathrm{cm})$ & $44.4 \pm 8.0$ & $48.3 \pm 7.7$ & $46.9 \pm 7.9$ \\
HL $(\mathrm{cm})$ & $8.2 \pm 1.3$ & $9.1 \pm 1.7$ & $8.8 \pm 1.6$ \\
BC $(\mathrm{cm})$ & $13.6 \pm 2.8$ & $14.6 \pm 4.0$ & $14.2 \pm 3.6$ \\
BW $(\mathrm{gram})$ & $378.0 \pm 93.9$ & $383.7 \pm 108.4$ & $381.7 \pm 102.0$ \\
\hline
\end{tabular}

Table 3. The relationship between length and weight in Hemiscyllium halmahera between sites including number of samples (N), coefficient a / b, R-square and growth pattern

\begin{tabular}{lccccc}
\hline Site & $\mathbf{N}$ & $\mathbf{a}$ & $\mathbf{b}$ & R-square & Growth pattern \\
\hline Maitara & 14 & 77.78 & 72.90 & 0.58 & + \\
Guraici & 6 & 248.75 & 11.96 & 0.72 & + \\
Loleo & 7 & 95.48 & 91.06 & 0.93 & + \\
Tidore & 2 & 0.99 & 3.39 & 1.00 & + \\
Total & 29 & 149.03 & 10.44 & 0.75 & + \\
\hline
\end{tabular}




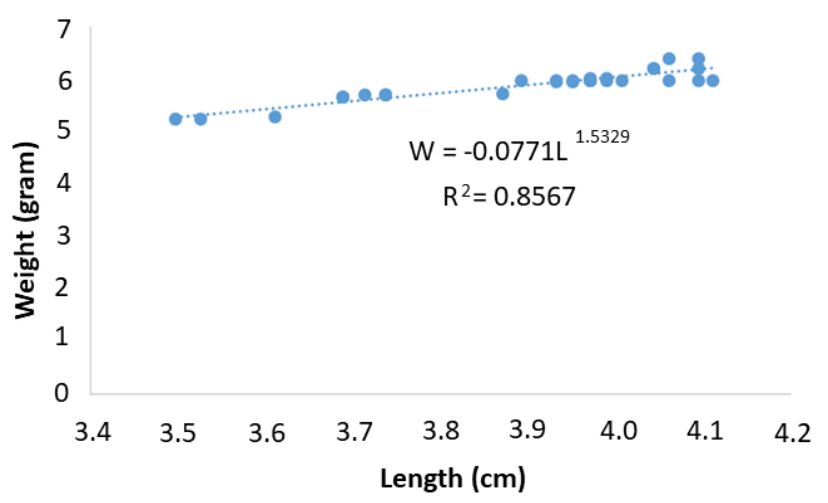

Figure 5. The relationship between length and weight in Hemiscyllium halmahera individuals.

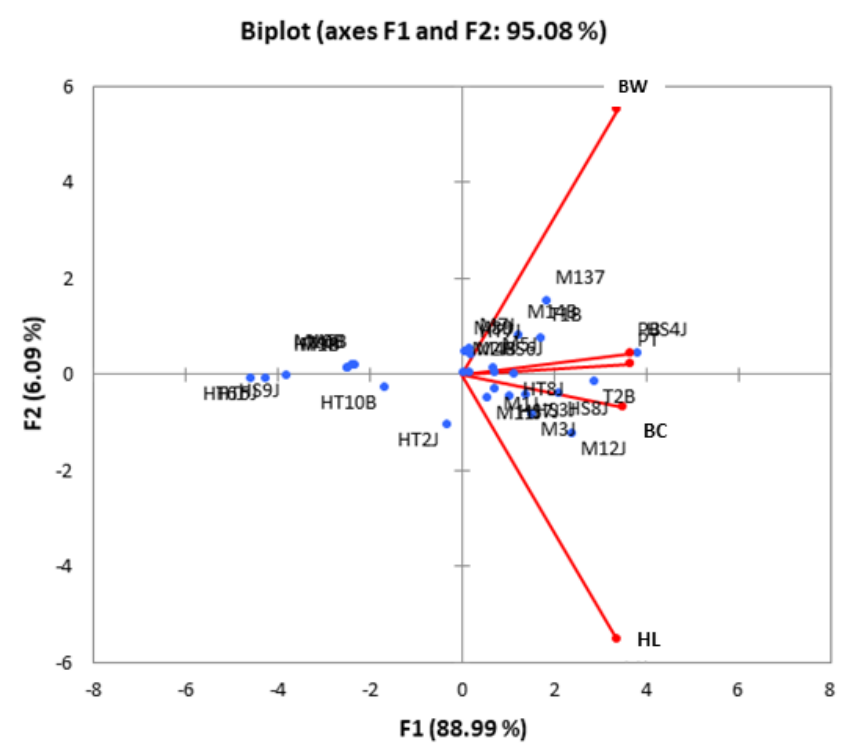

Figure 6. Analysis of principal components of morphometric characters including total length (TL), standard length (SL), head length (HL), body width (BW), and Weight (W) at all sites ( M: Maitara; HT: Halmahera Tengah; HS: Halmahera Selatan; T: Tidore) at F1 and F2 axis

Figure 6 shows the analysis of principal components of morphometric characters including total length (TL), standard length (SL), head length (HL), body width (BW), and total body weight (W) at all sites ( M: Maitara; HT: Halmahera Tengah; HS: Halmahera Selatan; T: Tidore) at the F1 and F2 axes. The difference in morphometric character sizes on $\mathrm{H}$. halmahera walking sharks taken at 5 different locations were analyzed through principal component analysis to view the total distribution of morphometric characters. The relationship between each of the morphometric characteristics of $H$. halmahera found at 5 distinct locations and sites are explained on the 2 main axes F1 and F2, with a range of $88.99 \%$ and $6.09 \%$ respectively, and root features at 4,450 and 0.305 . Morphometric characters such as total length, head length, body width, standard length, and weight have great similarities on Maitara Island, Tidore Island, and Guraici Island. However, in Loleo, the results were different from the three aforementioned locations.

\section{Molecular characteristics}

Table 4 Molecular identification of $H$. halmahera using Genbank's BLAST showing E Value, Query Cover (\%), and Percent Identification $(\%)$ and assigned species. The results obtained from the DNA fragment length analysis from all samples indicated about $793 \mathrm{bp}$. The results of all samples obtained were 32 tissues identified as $H$. halmahera consisting of 3 samples from Ternate Island, 14 samples from Maitara Island, 9 samples from Gura Ici Island (South Halmahera), 10 samples from Central Halmahera, and 2 samples from Tidore Island.

Figure 7 represents the reconstruction of phylogenetic tree markers mtDNA ND4 using Neighbour Joining and Maximum Likelihood (ML) Kimura 2 parameter models with a total of 1000 phylogenetic bootstrap values, respectively. The tree was formed from the results obtained from the analysis of 32 sequences and an additional 12 sequences from GenBank. The phylogenetic tree reconstruction was monophyletic with a total of 11 large classes representing each species. Each large class consists of sub-classes that indicate differences in the compositional structure of the nucleotide bases.

The genetic distances between these sequences are shown in Table 4. Analyses were conducted using the Kimura 2-parameter model (Kimura 1980; Tamura et al 2013). This analysis involved 32 nucleotide sequences in interspecies in which it has a low value of genetic distances. The K2P distance is the most effective model when genetic distances are low (Nijman and Aliabadian 2010). The maximum value of genetic distance within species $H$. halmahera was 0.0097 between ITK_Mai_WS_03 with ITK_Halsel_WS_03, ITK_Halteng_WS_01, ITK_Halteng_WS_05, and ITK_Halteng_WS_07.

Analysis of the genetic diversity value of Hemiscyllium halmahera in five distinct populations indicated the value of haplotype diversity and nucleotide diversity in regards to varying magnitude (Table 5). The results showed that 32 samples obtained 12 haplotypes, with the highest number of haplotypes observed in Loleo (five haplotypes) and the lowest number of haplotypes (one) in Tidore and Ternate populations. The highest haplotype diversity values were obtained at Loleo (0.805) and the lowest haplotype diversity value was found at Tidore and Ternate. The low values obtained might be due to the few samples that were available. The value of nucleotide diversity of the five populations also showed varied results. The highest nucleotide diversity was found in Guraici population of 0.0958 and the lowest was obtained in Tidore and Ternate.

\section{Discussion}

\section{Morphological characters}

The morphological characteristics of the Hemiscyllidae family are complex, and it is difficult to differentiate them through appearance alone According to Allen et al. (2013), the type of color patterns that are found in Hemiscyllium halmahera are similar to a few other species in this genus 
including $H$. strahani with black hood marks on its head, intense black marks on the body as in H. halstromi; small black spots on the whole of its outer body as in $H$. ocellatum, and a leopard-like pattern on its body is similar to $H$. michaeli. Like another elasmobranch, the male has a pair of clasper for the purpose of reproduction. According to Allen et al. (2016), each specie has a characteristic size that varies according to its biological class. Immature walking sharks have an average total length of classers of $500-600 \mathrm{~mm}$ which increases progressively until adulthood, and changes from small to large are likely to occur rapidly. Dark spots (smaller than eyes) are found around the muzzle area, brown spots are not too visible on the dorsal fin, 8-10 brown spots of varying sizes on the pectoral fins and 6-11 spots on the pelvic fins (Allen et al. 2016 ). In general, sharks of the Hemiscyllium genus breed by oviparous reproduction (Compagno 2002). Jutan et al. 2018, found 8-12 egg capsules on each stomach of fishes caught in the Kao bay, Halmahera islands, North Maluku,
Indonesia. Eggs of the bamboo shark species are encased in keratin capsules and the developing embryos rely on their egg yolk as food. These eggs have an outer adhesive filament that enhances their attachment to the coral or algae, thus preventing it from drifting into unfavorable environments (Michael 1993).

Table 5. Genetic diversity of H. Halmahera based on sample size (n), haplotype number (Hn), haplotype diversity (Hd), and nucleotide diversity $(\pi)$ from each of the population sites in North Maluku, Indonesia

\begin{tabular}{llccc}
\hline \multirow{2}{*}{ Site } & \multirow{n}{*}{} & \multicolumn{3}{c}{ Genetic diversity } \\
\cline { 3 - 5 } & & Hn & Hd & $\boldsymbol{\pi}$ \\
\hline Maitara & 14 & 2 & 0.1429 & 0.0005 \\
Loleo & 7 & 5 & 0.8056 & 0.0894 \\
Guraici & 6 & 3 & 0.4643 & 0.0958 \\
Tidore & 2 & 1 & 0 & 0 \\
Ternate & 3 & 1 & 0 & 0 \\
\hline
\end{tabular}

Table 4. Molecular identification of Hemiscyllium halmahera using Genbank's BLAST which shows the Value, Query Cover (\%) and Percent Identification (\%) and species

\begin{tabular}{|c|c|c|c|c|c|}
\hline Site & ID & Query cover & E value & Percent identification & Spesies \\
\hline Maitara & ITK Mai_WS 01 & $93 \%$ & 0.0 & $99.71 \%$ & Hemiscyllium halmahera \\
\hline Maitara & ITK_Mai_WS_02 & $93 \%$ & 0.0 & $99.71 \%$ & Hemiscyllium halmahera \\
\hline Maitara & ITK_Mai_WS_03 & $93 \%$ & 0.0 & $99.85 \%$ & Hemiscyllium halmahera \\
\hline Maitara & ITK_Mai_WS_04 & $93 \%$ & 0.0 & $99.71 \%$ & Hemiscyllium halmahera \\
\hline Maitara & ITK_Mai_WS_05 & $93 \%$ & 0.0 & $99.71 \%$ & Hemiscyllium halmahera \\
\hline Maitara & ITK_Mai_WS_06 & $93 \%$ & 0.0 & $99.71 \%$ & Hemiscyllium halmahera \\
\hline Maitara & ITK_Mai_WS_07 & $93 \%$ & 0.0 & $99.71 \%$ & Hemiscyllium halmahera \\
\hline Maitara & ITK_Mai_WS_08 & $93 \%$ & 0.0 & $99.71 \%$ & Hemiscyllium halmahera \\
\hline Maitara & ITK_Mai_WS_09 & $93 \%$ & 0.0 & $99.71 \%$ & Hemiscyllium halmahera \\
\hline Maitara & ITK_Mai_WS_10 & $93 \%$ & 0.0 & $99.71 \%$ & Hemiscyllium halmahera \\
\hline Maitara & ITK_Mai_WS_11 & $93 \%$ & 0.0 & $99.71 \%$ & Hemiscyllium halmahera \\
\hline Maitara & ITK_Mai_WS_12 & $93 \%$ & 0.0 & $99.71 \%$ & Hemiscyllium halmahera \\
\hline Maitara & ITK_Mai_WS_13 & $93 \%$ & 0.0 & $99.71 \%$ & Hemiscyllium halmahera \\
\hline Maitara & ITK_Mai_WS_14 & $93 \%$ & 0.0 & $99.71 \%$ & Hemiscyllium halmahera \\
\hline Guraici & ITK_Halsel_WS_03 & $93 \%$ & 0.0 & $99.85 \%$ & Hemiscyllium halmahera \\
\hline Guraici & ITK_Halsel_WS_04 & $93 \%$ & 0.0 & $99.71 \%$ & Hemiscyllium halmahera \\
\hline Guraici & ITK_Halsel_WS_06 & $93 \%$ & 0.0 & $99.71 \%$ & Hemiscyllium halmahera \\
\hline Guraici & ITK_Halsel_WS_07 & $93 \%$ & 0.0 & $99.71 \%$ & Hemiscyllium halmahera \\
\hline Guraici & ITK_Halsel_WS_08 & $93 \%$ & 0.0 & $99.71 \%$ & Hemiscyllium halmahera \\
\hline Guraici & ITK_Halsel_WS_09 & $93 \%$ & 0.0 & $99.71 \%$ & Hemiscyllium halmahera \\
\hline Loleo & ITK_Halteng_WS_01 & $93 \%$ & 0.0 & $99.85 \%$ & Hemiscyllium halmahera \\
\hline Loleo & ITK_Halteng_WS_02 & $93 \%$ & 0.0 & $99.71 \%$ & Hemiscyllium halmahera \\
\hline Loleo & ITK_Halteng_WS_05 & $93 \%$ & 0.0 & $99.85 \%$ & Hemiscyllium halmahera \\
\hline Loleo & ITK_Halteng_WS_06 & $93 \%$ & 0.0 & $99.71 \%$ & Hemiscyllium halmahera \\
\hline Loleo & ITK_Halteng_WS_07 & $93 \%$ & 0.0 & $99.85 \%$ & Hemiscyllium halmahera \\
\hline Loleo & ITK_Halteng_WS_08 & $93 \%$ & 0.0 & $99.71 \%$ & Hemiscyllium halmahera \\
\hline Loleo & ITK_Halteng_WS_10 & $93 \%$ & 0.0 & $99.71 \%$ & Hemiscyllium halmahera \\
\hline Tidore & ITK_Tidore_WS_01 & $93 \%$ & 0.0 & $99.71 \%$ & Hemiscyllium halmahera \\
\hline Tidore & ITK_Tidore_WS_02 & $93 \%$ & 0.0 & $99.71 \%$ & Hemiscyllium halmahera \\
\hline Ternate & ITK_Ternate_Hiu_01 & $93 \%$ & 0.0 & $99.71 \%$ & Hemiscyllium halmahera \\
\hline Ternate & ITK_Ternate_Hiu_02 & $93 \%$ & 0.0 & $99.71 \%$ & Hemiscyllium halmahera \\
\hline Ternate & ITK_Ternate_Hiu_03 & $93 \%$ & 0.0 & $99.71 \%$ & Hemiscyllium halmahera \\
\hline
\end{tabular}




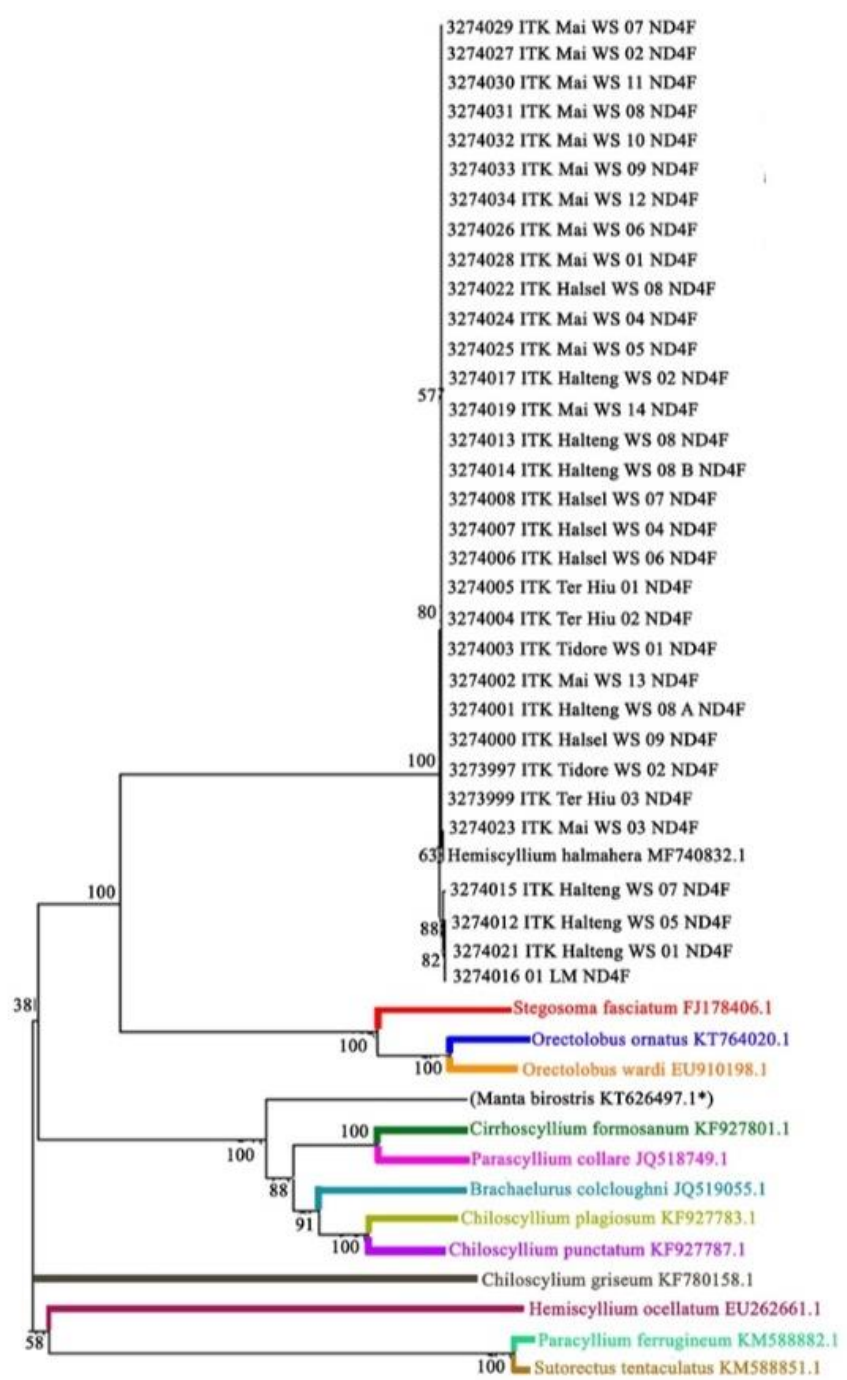

$\lceil 0.05$

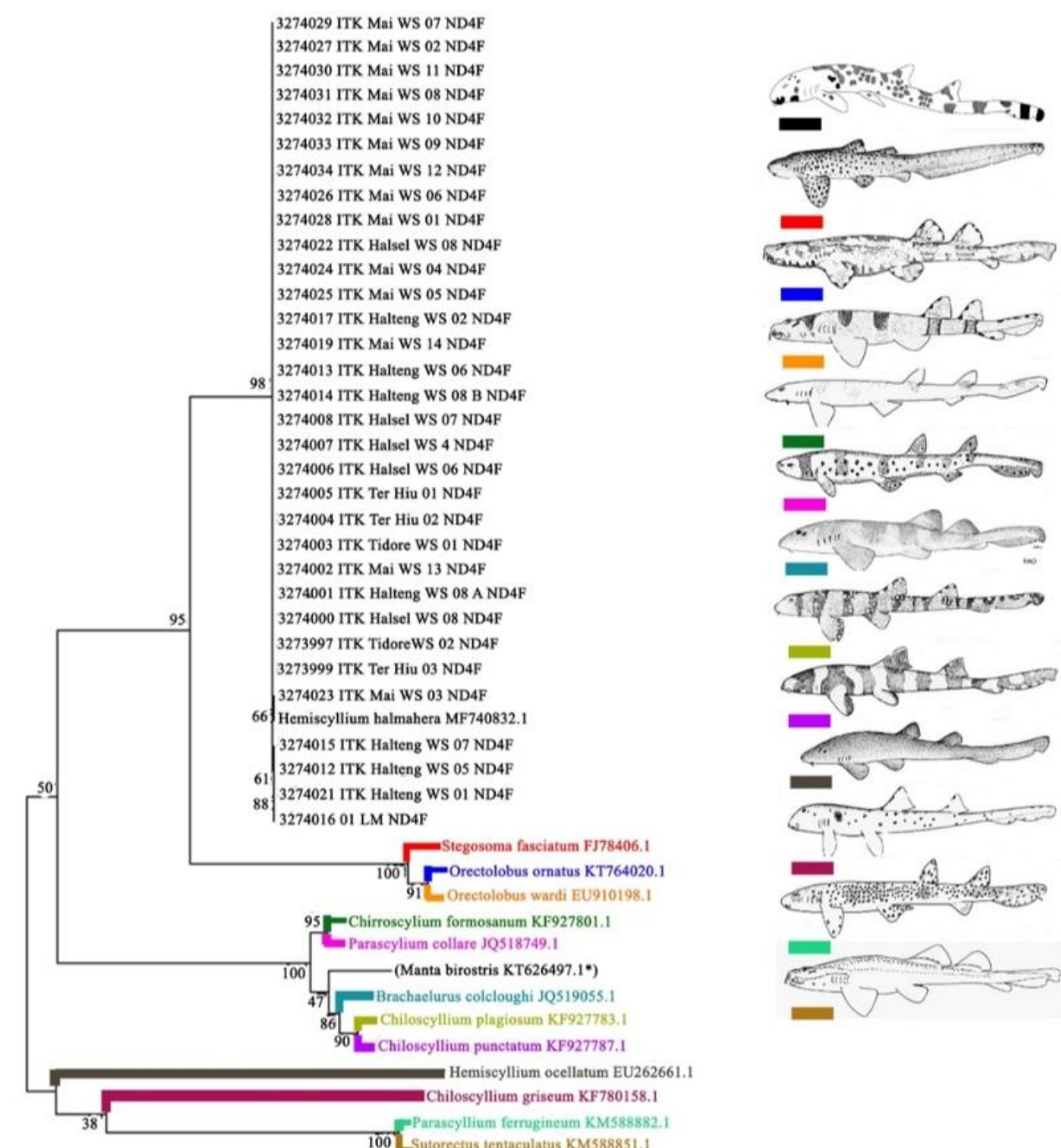

A

5.2

Figure 7. Reconstruction of the phylogenic tree of 32 sequences of Hemycyllium halmahera with 12 additional sequences from GenBank using Neighbor-Joining (A) and Maximum Likelihood (B) based on P-Distance method with 1000 bootstraps (Except Hemycyllium Halmahera, other sketches sourced from FAO (2019), www.fao.org) 
Table 4. Pairwise comparisons based on mean K2P distances within Hemycyllium halmahera species

\begin{tabular}{|c|c|c|c|c|c|c|c|c|c|c|c|c|c|c|c|c|c|c|c|c|c|c|c|c|c|c|c|c|c|c|c|c|c|}
\hline No & Sample ID & 1 & 2 & 3 & 4 & 5 & 6 & 7 & 8 & 9 & 10 & 11 & 12 & 13 & 14 & 15 & 16 & 17 & 18 & 19 & 20 & 21 & 22 & 23 & 24 & 25 & 26 & 27 & 28 & 29 & 30 & 31 & 32 \\
\hline 1 & $\begin{array}{l}\text { ITK_Mai_WS_01 } \\
\end{array}$ & & & & & & & & & & & & & & & & & & & & & & & & & & & & & & & & \\
\hline 2 & ITK_Mai_WS_02 & 0.0000 & & & & & & & & & & & & & & & & & & & & & & & & & & & & & & & \\
\hline 3 & ITK_Mai_WS_03 & 0.0041 & 0.0041 & & & & & & & & & & & & & & & & & & & & & & & & & & & & & & \\
\hline 4 & ITK_Mai_WS_04 & 0.0000 & 0.0000 & 0.0041 & & & & & & & & & & & & & & & & & & & & & & & & & & & & & \\
\hline 5 & ITK_Mai_WS_05 & 0.0000 & 0.0000 & 0.0041 & 0.0000 & & & & & & & & & & & & & & & & & & & & & & & & & & & & \\
\hline 6 & ITK_Mai_WS_06 & 0.0000 & 0.0000 & 0.0041 & 0.0000 & 0.0000 & & & & & & & & & & & & & & & & & & & & & & & & & & & \\
\hline 7 & ITK_Mai_WS_07 & 0.0000 & 0.0000 & 0.0041 & 0.0000 & 0.0000 & 0.0000 & & & & & & & & & & & & & & & & & & & & & & & & & & \\
\hline 8 & ITK_Mai_WS_08 & 0.0000 & 0.0000 & 0.0041 & 0.0000 & 0.0000 & 0.0000 & 0.0000 & & & & & & & & & & & & & & & & & & & & & & & & & \\
\hline 9 & ITK_Mai_WS_09 & 0.0000 & 0.0000 & 0.0041 & 0.0000 & 0.0000 & 0.0000 & 0.0000 & 0.0000 & & & & & & & & & & & & & & & & & & & & & & & & \\
\hline 10 & ITK_Mai_WS_10 & 0.0000 & 0.0000 & 0.0041 & 0.0000 & 0.0000 & 0.0000 & 0.0000 & 0.0000 & 0.0000 & & & & & & & & & & & & & & & & & & & & & & & \\
\hline 11 & ITK_Mai_WS_11 & 0.0000 & 0.0000 & 0.0041 & 0.0000 & 0.0000 & 0.0000 & 0.0000 & 0.0000 & 0.0000 & 0.0000 & & & & & & & & & & & & & & & & & & & & & & \\
\hline 12 & ITK_Mai_WS_12 & 0.0000 & 0.0000 & 0.0041 & 0.0000 & 0.0000 & 0.0000 & 0.0000 & 0.0000 & 0.0000 & 0.0000 & 0.0000 & & & & & & & & & & & & & & & & & & & & & \\
\hline 13 & ITK_Mai_WS_13 & 0.0000 & 0.0000 & 0.0041 & 0.0000 & 0.0000 & 0.0000 & 0.0000 & 0.0000 & 0.0000 & 0.0000 & 0.0000 & 0.0000 & & & & & & & & & & & & & & & & & & & & \\
\hline 14 & ITK_Mai_WS_14 & 0.0000 & 0.0000 & 0.0041 & 0.0000 & 0.0000 & 0.0000 & 0.0000 & 0.0000 & 0.0000 & 0.0000 & 0.0000 & 0.0000 & 0.0000 & & & & & & & & & & & & & & & & & & & \\
\hline 15 & ITK_Halsel_WS_03 & 0.0083 & 0.0083 & 0.0097 & 0.0083 & 0.0083 & 0.0083 & 0.0083 & 0.0083 & 0.0083 & 0.0083 & 0.0083 & 0.0083 & 0.0083 & 0.0083 & & & & & & & & & & & & & & & & & & \\
\hline 16 & ITK_Halsel_WS_04 & 0.0000 & 0.0000 & 0.0041 & 0.0000 & 0.0000 & 0.0000 & 0.0000 & 0.0000 & 0.0000 & 0.0000 & 0.0000 & 0.0000 & 0.0000 & 0.0000 & 0.0083 & & & & & & & & & & & & & & & & & \\
\hline 17 & ITK_Halsel_WS_06 & 0.0000 & 0.0000 & 0.0041 & 0.0000 & 0.0000 & 0.0000 & 0.0000 & 0.0000 & 0.0000 & 0.0000 & 0.0000 & 0.0000 & 0.0000 & 0.0000 & 0.0083 & 0.0000 & & & & & & & & & & & & & & & & \\
\hline 18 & ITK_Halsel_WS_07 & 0.0000 & 0.0000 & 0.0041 & 0.0000 & 0.0000 & 0.0000 & 0.0000 & 0.0000 & 0.0000 & 0.0000 & 0.0000 & 0.0000 & 0.0000 & 0.0000 & 0.0083 & 0.0000 & 0.0000 & & & & & & & & & & & & & & & \\
\hline 19 & ITK_Halsel_WS_08 & 0.0000 & 0.0000 & 0.0041 & 0.0000 & 0.0000 & 0.0000 & 0.0000 & 0.0000 & 0.0000 & 0.0000 & 0.0000 & 0.0000 & 0.0000 & 0.0000 & 0.0083 & 0.0000 & 0.0000 & 0.0000 & & & & & & & & & & & & & & \\
\hline 20 & ITK_Halsel_WS_09 & 0.0000 & 0.0000 & 0.0041 & 0.0000 & 0.0000 & 0.0000 & 0.0000 & 0.0000 & 0.0000 & 0.0000 & 0.0000 & 0.0000 & 0.0000 & 0.0000 & 0.0083 & 0.0000 & 0.0000 & 0.0000 & 0.0000 & & & & & & & & & & & & & \\
\hline 21 & ITK_Halteng_WS_01 & 10.0083 & 0.0083 & 0.0097 & 0.0083 & 0.0083 & 0.0083 & 0.0083 & 0.0083 & 0.0083 & 0.0083 & 0.0083 & 0.0083 & 0.0083 & 0.0083 & 0.0000 & 0.0083 & 0.0083 & 0.0083 & 0.0083 & 0.0083 & & & & & & & & & & & & \\
\hline 22 & ITK_Halteng_WS_02 & 20.0000 & 0.0000 & 0.0041 & 0.0000 & 0.0000 & 0.0000 & 0.0000 & 0.0000 & 0.0000 & 0.0000 & 0.0000 & 0.0000 & 0.0000 & 0.0000 & 0.0083 & 0.0000 & 0.0000 & 0.0000 & 0.0000 & 0.0000 & 0.0083 & & & & & & & & & & & \\
\hline 23 & ITK_Halteng_WS_05 & 0.0083 & 0.0083 & 0.0097 & 0.0083 & 0.0083 & 0.0083 & 0.0083 & 0.0083 & 0.0083 & 0.0083 & 0.0083 & 0.0083 & 0.0083 & 0.0083 & 0.0000 & 0.0083 & 0.0083 & 0.0083 & 0.0083 & 0.0083 & 0.0000 & 0.0083 & & & & & & & & & & \\
\hline 24 & ITK_Halteng_WS_06 & 50.0000 & 0.0000 & 0.0041 & 0.0000 & 0.0000 & 0.0000 & 0.0000 & 0.0000 & 0.0000 & 0.0000 & 0.0000 & 0.0000 & 0.0000 & 0.0000 & 0.0083 & 0.0000 & 0.0000 & 0.0000 & 0.0000 & 0.0000 & 0.0083 & 0.0000 & 0.0083 & & & & & & & & & \\
\hline 25 & ITK_Halteng_WS_07 & 0.0083 & 0.0083 & 0.0097 & 0.0083 & 0.0083 & 0.0083 & 0.0083 & 0.0083 & 0.0083 & 0.0083 & 0.0083 & 0.0083 & 0.0083 & 0.0083 & 0.0028 & 0.0083 & 0.0083 & 0.0083 & 0.0083 & 0.0083 & 0.0028 & 0.0083 & 0.0028 & 0.0083 & & & & & & & & \\
\hline 26 & ITK_Halteng_WS_08 & 0.0000 & 0.0000 & 0.0041 & 0.0000 & 0.0000 & 0.0000 & 0.0000 & 0.0000 & 0.0000 & 0.0000 & 0.0000 & 0.0000 & 0.0000 & 0.0000 & 0.0083 & 0.0000 & 0.0000 & 0.0000 & 0.0000 & 0.0000 & 0.0083 & 0.0000 & 0.0083 & 0.0000 & 0.0083 & & & & & & & \\
\hline 27 & ITK_Halteng_WS_10 & 0.0000 & 0.0000 & 0.0041 & 0.0000 & 0.0000 & 0.0000 & 0.0000 & 0.0000 & 0.0000 & 0.0000 & 0.0000 & 0.0000 & 0.0000 & 0.0000 & 0.0083 & 0.0000 & 0.0000 & 0.0000 & 0.0000 & 0.0000 & 0.0083 & 0.0000 & 0.0083 & 0.0000 & 0.0083 & 0.0000 & & & & & & \\
\hline 28 & ITK_Tidore_WS_01 & 0.0000 & 0.0000 & 0.0041 & 0.0000 & 0.0000 & 0.0000 & 0.0000 & 0.0000 & 0.0000 & 0.0000 & 0.0000 & 0.0000 & 0.0000 & 0.0000 & 0.0083 & 0.0000 & 0.0000 & 0.0000 & 0.0000 & 0.0000 & 0.0083 & 0.0000 & 0.0083 & 0.0000 & 0.0083 & 0.0000 & 00.0000 & & & & & \\
\hline 29 & ITK_Tidore_WS_02 & 0.0000 & 0.0000 & 0.0041 & 0.0000 & 0.0000 & 0.0000 & 0.0000 & 0.0000 & 0.0000 & 0.0000 & 0.0000 & 0.0000 & 0.0000 & 0.0000 & 0.0083 & 0.0000 & 0.0000 & 0.0000 & 0.0000 & 0.0000 & 0.0083 & 0.0000 & 0.0083 & 0.0000 & 0.0083 & 0.0000 & 00.0000 & 0.0000 & & & & \\
\hline 30 & ITK_Ter_Hiu_01 & 0.0000 & 0.0000 & 0.0041 & 0.0000 & 0.0000 & 0.0000 & 0.0000 & 0.0000 & 0.0000 & 0.0000 & 0.0000 & 0.0000 & 0.0000 & 0.0000 & 0.0083 & 0.0000 & 0.0000 & 0.0000 & 0.0000 & 0.0000 & 0.0083 & 0.0000 & 0.0083 & 0.0000 & 0.0083 & 0.0000 & 00.0000 & 0.0000 & 0.0000 & & & \\
\hline 31 & ITK_Ter_Hiu_02 & 0.0000 & 0.0000 & 0.0041 & 0.0000 & 0.0000 & 0.0000 & 0.0000 & 0.0000 & 0.0000 & 0.0000 & 0.0000 & 0.0000 & 0.0000 & 0.0000 & 0.0083 & 0.0000 & 0.0000 & 0.0000 & 0.0000 & 0.0000 & 0.0083 & 0.0000 & 0.0083 & 0.0000 & 0.0083 & 0.0000 & 00.0000 & 0.0000 & 0.0000 & 0.0000 & & \\
\hline 32 & ITK_Ter_Hiu_03 & 0.0000 & 0.0000 & 0.0041 & 0.0000 & 0.0000 & 0.0000 & 0.0000 & 0.0000 & 0.0000 & 0.0000 & 0.0000 & 0.0000 & 0.0000 & 0.0000 & 0.0083 & 0.0000 & 0.0000 & 0.0000 & 0.0000 & 0.0000 & 0.0083 & 0.0000 & 0.0083 & 0.0000 & 0.0083 & 0.0000 & 00.0000 & 0.0000 & 0.0000 & 0.0000 & 0.000 & \\
\hline
\end{tabular}


The body length of sharks of the Hemiscyllium genus is indeed small; usually not more than $80 \mathrm{~cm}$ (Allen et al. 2013), similar to the findings of this study in which results of morphometric measurement indicated that the total length of the walking shark samples were not more than 75 $\mathrm{cm}$ with an average $52.3 \pm 10.2 \mathrm{~cm}$, for both male and female. This study also observed that the male is larger than the female. The length-weight analysis was carried out to ascertain the biological conditions of these fish samples to facilitate the management of the survival of fish biodiversity (Froese 2006, Rosli and Isa 2012). The analytical results of the length-weight relationship show that the growth type of $H$. halmahera is a positive allometric. The difference in $b$ values is due to several influencing factors, such as season and location/site differences, temperature and salinity differences, sex, food availability, and differences in the number of samples used (Tesch 1971; Moutopoulus et al. 2002; Froese 2006). The length-weight relationship in Hemiscyllium halmahera from the value of the constant $b$ indicates that the weight of this shark is disproportionately faster than the length or also called positive allometric (Effendie 1979), as this study found.

\section{Molecular characteristics}

This study confirmed through DNA Barcoding that the samples collected from the Halmahera Archipelago are Hemiscyllium halmahera. Phylogenetically, the class formed comes from a sample that has common similarities and forms a sub-class. Samples obtained from the various study sites formed a separate class and therefore, are not included Orectolobiformes order. The genetic distance within $H$. halmahera species samples are very closed, so it can be ascertained that the species originating from Halmahera waters are $H$. halmahera species, as they are also grouped with a sequence H. Halmahera (MF740832.1) from GenBank, as reference. The closest species occurred between $H$. halmahera and $H$. Ocellatum, but they have different habitat Distribution of $H$. ocellatum species in Queensland Australia beginning from the north of the Cape York Peninsula to the southern Great Barrier Reef (Allen et al. 2016). These population variances occur due to differences in environment or habitats; and this condition could affect genetic materials within an individual amongst a species (Freeland 2005). Chiloscyllium sp. forming a distant class with $H$. halmahera. Based on morphology, these two species possess the same characteristics. According to Compagno (2002), the difference between these two species is that a black hood-shaped pattern is absent on the head of the Chiloscyllium and there are no black spots at the sides of the body above the pectoral fins, or elongated snout tips, and no subterminal nostrils. Sequence results are obtained from Australia to ensure that distant habitat differences affect the genetic distance values significantly.

The geographical distance between populations can significantly affect genetic diversity even in haplotypes. This theory is supported by Bramandito et al. (2018), which affirms that the greater the distance between populations, the greater the difference in base order.
According to Nei (1987), the haplotype diversity values in the Loleo population are to be included in the high category, while that of Guraici is to be found in the moderate category. The population in Tidore, Ternate, and Maitara show low values of haplotype diversity. The high value of haplotype diversity is inferred to be due to the large population size still available in the local waters of the country. The migration factor will also significantly affect the high value of haplotype diversities for a population, and this is because a population migration will result in inter-population encounters that allow for interbreeding and gene mixing between population members. (Akbar et al. 2014, Pertiwi et al. 2017, Akbar et al. 2020). Based on the analytical results obtained (Table 1 ), the diversity value of haplotypes and nucleotides of Tidore and Ternate populations each are equal to 0 . This is because the haplotype numbers formed in Tidore and Ternate populations is one, and this study opines that there are no differences between individuals in the population of Tidore and Ternate. This is allegedly due to the small size of their respective populations, as seen from the number of samples, which would otherwise have indicated that the data was not processed properly. According to Kliman et al. (2008), high genetic diversity reflects a large population size.

Overfishing of certain populations of fishes also could affect its genetic diversity. Hemiscyllium species are not widely used for fisheries other than trading for aquariums (Compagno 2002). According to Jutan et al. (2018), the local fishermen catch the $H$. halmahera for meat consumption, and sometimes they are sold alive, to be used as aquarium pets. The low nucleotide diversity values indicate that each individual shark in a population has a close kinship $(\pi=0)$. The genetic diversity of $H$. halmahera among the distinct populations is influenced by the poor migratory ability of this swimming (its travel capacity is limited). According to Akbar et al. (2014) and Pertiwi et al. (2017), the similarity of genetic diversity is characteristic of fishes with high migration rates. The extensive migration zone makes for meetings between various populations and increases the possibilities of marriage between them (inbreeding). This statement, therefore, agrees with the reviews of Hughes et al. (2008) that the magnitude of genetic diversity is dependent on, and influenced by widespread and mixed biological systems, as this study found a high genetic diversity $H$. halmahera in the Loleo population. Furthermore, it was inferred that the relatively low genetic diversities in the Tidore and Ternate populations are due to the small number of samples.

Human activities that cause pollution and habitat degradation, as well as climate change, could adversely affect the Halmahera walking shark population. Also, their reproductive system makes available only two eggs at a time and requires $>4$ months to hatch, which increases the vulnerability of this species. (Jutan et al. 2018). Habitat fragmentation and environmental instability caused by human activities can result in gene flow restrictions and increased random genetic drift. Extinction and dynamics of recolonization in local populations can also cause changes in the distribution of genetic variability, which could lead 
to either an increase or decrease in variation among populations (Arnaud et al. 1999).

In conclusion, DNA sub-sequence analysis indicates that the sequences found in this species are different from those found in the Australia-New Guinea region. This species is distinguished by their unique color patterns, specifically the light-brown background color of their body with lots of black spots scattered around the dorsal and pectoral fins. The walking shark has a brown color on the snout, head, and body with a gradation of golden brown on the lower aspect of its body and white on the ventral aspect. Therefore, this study has successfully identified Hemiscyllium halmahera based on their morphological and molecular characters, and has also contributed to the international genetic database (Barcoding Of Life Database-BOLD) for further studies.

\section{ACKNOWLEDGEMENTS}

This study is funded by RISTEK DIKTI scheme Penelitian Berbasis Kompetensi entitled "Penelitian dengan judul Aplikasi Genomika dan Metabarkoding DNA Lingkungan (eDNA) Hiu Berjalan Endemik Hemiscyllium halmahera dalam Upaya Deteksi Habitat dan Konservasi Jenis di Halmahera" awarded to principal invertigator, HM. We would like to extend our gratitude to lab assistance of Scientific Diving of IPB University, Bogor, Indonesia for diving equipment provisions and to Marine Biodiversity and Biosystematics of IPB University for genetic lab equipment and support.

\section{REFERENCES}

Akbar N, Pertiwi D, Neviaty P Zamani NP, Subhan B, Madduppa H. 2020. A pilot study on the population genetics of yellowfin tuna (Thunnus albacares) from two populations in the Moluccas Islands, Indonesia. Depik 9 (1): 69-106.

Akbar N, Zamani NP, Madduppa HH. 2014. Keragaman genetik ikan tuna sirip kuning (Thunnus albacares) dari dua populasi di Laut Maluku, Indonesia. Depik. 3 (1): 65-73. [Indonesian]

Allen GR, Erdmann MV, Dudgeon CL. 2013. Hemiscyllium halmahera, a new species of Bamboo Shark (Hemiscyllidae) from Indonesia. Aqua J Ichtiol 19 (3): 123-136.

Allen GR, Erdmann MV, White WT, Fahmi, Dudgeon CL. 2016. Review of the Bamboo Shark genus Hemiscyllium (Orecolobiformes: Hemiscyllidae). Journal of The Ocean Science Foundation. 23: 51-97. DOI: 105281/zenodo.164197.

Almerón-Souza F, Sperb C, Castilho CL, Figueiredo PICC, Gonçalves LT, Machado R, Oliveira LR, Valiati VH, Fagundes NJR. 2018. Molecular identification of shark meat from local markets in southern brazil based on dna barcoding: evidence for mislabeling and trade of endangered species. Front Genet 9: 138. DOI: 10.3389/fgene.2018.00138

Arevalo E, Davis SK, Sites JW. 1994. Mitochondrial-DNA sequence divergence and phylogenetic relationships among eight chromosome races of the Sceloporus-Grammicus complex (Phrynosomatide) in central Mexico. Syst Biol 43: 387-418.

Arnaud JF, Madec L, Bellido A, Guiller A. 1999. Microspatial genetic structure in the land snail Helix aspersa (Gastropoda: Helicidae). Heredity 83: 110-119.

Bramandito A, Subhan B, Prartono T, Anggraini NP, Januar HI, Madduppa HH. 2018. Genetic diversity and population structure of Siganus fuscescens across urban riffs of Seribu Islands, Northern of Jakarta, Indonesia. Biodiversitas 19 (6): 1993-2002.
Coenye T, Vandamme P. 2003. Extracting phylogenic information from whole-genome sequencing projects: the lactic acid bacteria as a test case. Microbiology. 149: 3507-3517.

Compagno LJV. 2002. Shark of the World An Annotated and Illustrated Catalogue Of Shark Species Known To Date Volume 2. FAO, Rome.

Effendie MI. 1979. Method on Fish Biology. Institut Pertanian Bogor \& Yayasan Agromedia, Bogor. [Indonesian]

Excoffieer L, Lischer HL. 2010. Arlequin suite ver 3.5: a new series of programs to perform population genetics analyses under Linux and Windows. Molecular Ecology Resources 10, 564-567

Food and Agriculture Organisation of the United Nations [FAO]. 2015. Onboard guide for the identification of pelagic shark and rays of the Western Indian Ocean. Indian Ocean Commissions.

Freeland R. 2005. Molecular Ecology. John Wiley \& Sons. Ltd., England, UK.

Froese R. 2006. Cube law, condition factor and weight-length relationships: history, meta-analysis and recommendations. J Appl Ichthyol 22 (4): 241-253

Hellberg RS, Isaacs RB, Hernandez EL2019. Identification of shark species in commercial products using DNA barcoding. Fish Res 21: $81-88$

Horiike T, Miyata D, Hamada K, Saruhasi S, Shinozawa T, Kumar S, Chakraborty R, Komiyama T, Tateno Y. 2009. Phylogenetic construction of 17 bacterial phyla by new method and carefully selected orthologs. Genetic 429: 56-64.

Hughes AR, Inouye BD, Johnson MTJ, Underwood N, Vellend M (2008) Ecological consequences of genetic diversity. Ecology Letters, https://doi.org/10.1111/j.1461-0248.2008.01179.x

Inoue JG, Miya M, Tsukamoto K, Nishida M. 2001. A mitogenomic perspective on the basal teleostean phylogeny: Resolving higher-level relationships with longer DNA sequences. Mol Phylogenet Evol Biol 9: 235.

Jutan Y, Retraubun ASW, Khouw AS, Nikijuluw VPH. 2017. Kondisi ikan hiu berjalan Halmahera (Hemiscyllium halmahera) di periran Teluk Kao, Halmahera Utara Provinsi Maluku Utara. Prosiding Seminar Nasional KSP2K II. 1 (2): 194-205. [Indonesian]

Jutan Y, Retraubun ASW, Khouw AS, Nikijuluw, Pattikawa JA. 2018. Study on the population of Halmahera walking shark (Hemiscyllium halmahera) in Kao Bay, North Maluku, Indonesia. Intl J Fish Aquat Stud 6 (4): 36-41.

Kimura M. 1980. A simple method for estimating evolutionary rates of base substitutions 495 through comparative studies of nucleotide sequences. J Mol Evol 16: 111-120.

Kliman R, Sheehy B, Schultz J (2008) Genetic Drift and Effective Population Size. Nature Education 1(3):3

Madduppa H, Ayuningtyas RU, Subhan B, Arafat D, Prehadi. 2016. Exploited but unevaluated: DNA barcoding reveals skates and stingrays (Chordata, Chondrichthyes) species landed in the Indonesian fish market. Ilmu Kelautan 21 (1): 29-36.

Metzker ML (2005) Emerging technologies in DNA sequencing. Genome Research. 15:1767-1776

Meirmans PG, Liu S. 2018. Analysis of molecular variance (AMOVA) for autopolyploids. Frontiers in Ecology and Evolution. 6 (66): 1-10.

Michael SW. 1993. Reef Sharks and Rays of the World. Lighthouse Press, Annapolis, USA.

Momigliano P, Harcourt R, Robbins WD, Jaiteh V, Mahardika GN Sembiring A, Stow A .2017. Genetic structure and signatures of selection in grey reef sharks (Carcharhinus amblyrhynchos) Heredity 119: $142-153$

Moutopoulus DK, Stergiou KI. 2002. Length-weight and length-length relationships of fish species from Aegean Sea (Greece). J Appl Ichthyol 18 (3) 200-203.

Nei M. 1987. Molecular Evolutionary Genetics. Columbia University. Press. New York.

Pertiwi NPD, Nugraha B, Kartika R, Sulistyaningsih, Jatmiko R, Sembiring A, Mahardini A, Cahyani NKD, Anggoro AW, Madduppa $\mathrm{HH}$, Ambariyanto A, Barber PH, Mahardika GN. 2017. Lack of differentiation within the bigeye tuna population of Indonesia. Biodiversitas 8 (4): 1406-1413.

Prehadi, Sembiring A, Kurniasih EM, Rahmad, Arafat D, Subhan B, Madduppa HH. 2015. DNA barcoding and phylogenetic reconstruction of shark species landed in Muncar fisheries landing site in comparison with Southern Java fishing port. Biodiversitas 15 (1): 55-61.

Rosli NAM, Isa MM. 2012. Length-weight and length-length relationship of longsnouted catfish, Plicofollis argyropleuron (Valenciennes 1840) 
in the Northern part of Peninsular Malaysia. J Tropical Life Science Reasearch. 23 (2): 59-65.

Rozas J, Sanches-DelBarrio J C, Messeguer X, Rozas R. 2003. DnaSp, DNA polymorphism analyses by the coalescent and other methods. Bioinformatics. 19 (18): 2496-2497

Sallis H, Smith GD, Munafò MR (2018) Genetics of biologically based psychological differences. Philos Trans R Soc Lond B Biol Sci. 373(1744): 20170162. doi: 10.1098/rstb.2017.0162

Sembiring A, Pertiwi NPD, Mahardini A, Wulandari R, Kurniasih EM, Kuncoro AW, Cahyani NKD, Anggoro A, Ulfa M, Madduppa H, Carpenter KE, Barber PH, Mahardika GN. 2014. DNA barcoding reveals targeted fisheries for endangered sharks in Indonesia. Fish Res DOI: 10.1016/j.fishres.2014.11.003
Subur R, Sarni. 2018. Kapasitas Adaptif Mangrove Pada Pulau Kecil Mikro Studi Di Pulau Maitara Kota Tidore Kepulauan Propinsi Maluku Utara. Jurnal Biologi Tropis 18 (2): 123-133. DOI: 10.29303/jbt.v18i2.801. [Indonesian]

Tamura K, Stecher G, Peterson D, Filipski A, Kumar S. 2013. MEGA 6: molecular evolutionary genetics analysis version 6.0. Mol Biol Evol. 30 (12): 1725-2729. DOI: $10.1093 / \mathrm{molbev} / \mathrm{mst} 197$.

Tesch F. 1971. Age and growth. In: Ricker WE (ed.) Methods for Assessment of Fish Production in Fresh Waters. Blackwell Scientific Publications, Oxford, UK.

Walsh PS, Metzger DA, Higuchi R. 1991. Chelex 100 as a medium for simple extraction of DNA for PCR-based typing from forensic material. Biotechnique 10 (4): 506-513. 